\title{
Prevalence of Premarital Sexual Practice and Its Associated Factors Among Senior Students in Alage Technical Vocational Education Training College, Ministry of Agriculture and Natural Resource, Ethiopia
}

\author{
Manale Andargie Embiyale \\ Debremarkos University, College of Agriculture, Ethiopia. PO box 269
}

\begin{abstract}
The study was conducted to explore the prevalence of premarital sexual practice and its associated factors among senior students in Alage ATVET College, Ministry of Agriculture and Natural Resource, Ethiopia. A crosssectional survey was conducted on 363 systematically selected students by using self-administered questionnaire and complimented by a qualitative data. The data was entered, cleaned and analyzed by using SPSS version 20 . Bivariate and multivariate logistic regressions were used for quantitative data analysis while thematic presentation was used for qualitative data. Odds ratio with $95 \%$ confidence interval was used to measure the strength and significance of the association. In this study, more than half $188(53 \%)$ of the participants had premarital sexual experience, of which $131(69.7 \%)$ were males and $57(30.3 \%)$ were females. The mean age at first sexual intercourse was 18.12 for males and 17.07 for females. The main reasons reported for initiation of premarital sexual intercourse were personal interest to try sex(36.17\%), peer pressure $(26.6 \%)$ and to get money or gifts $22(11.7 \%)$. While male $\operatorname{sex}[\mathrm{AOR}=3.33,95 \% \mathrm{CI}(1.2-9.24)]$, having pocket money[AOR=9.63, 95\% $\mathrm{CI}(3.61-25.79)]$, watching pornography[AOR $=1.34,95 \% \mathrm{CI}(0.45-3.98)]$, having sexual experienced friends $[\mathrm{AOR}=2.97,95 \% \mathrm{CI}(1.06-8.32)]$, alcohol drinking $[\mathrm{AOR}=1.54 ; 95 \% \mathrm{CI}(0.59-4.01)]$ and dating experience $[\mathrm{AOR}=42.43,95 \% \mathrm{CI}(14.93-120.62)]$ were found to be statically significant predictors of premarital sexual practice. In conclusion, this particular study indicated that a substantial proportion of youths were practicing premarital sexual practices that predispose them to different reproductive health problems. Therefore, there is a need for institutions of higher education to develop skill building programs and policies that will assure a safe institutional environment, promote access to health care and sex education, encourage peer counseling and parental communication.
\end{abstract}

Keywords: prevalence, premarital sex, risky sexual practice, factors of premarital sex, Alage Technical Vocational Education Training College.

DOI: $10.7176 /$ RHSS/9-19-03

Publication date:October $31^{\text {st }} 2019$

\section{Introduction}

Worldwide the prevalence of risky sexual practice was elevated at higher level and young people's experiences related to sex vary across the world because of various socio-cultural factors. Sub-Saharan Africa remains the region most severely affected by the HIV epidemic while risky sexual behavior is superficially increase among students in the higher education institutions (MDG Report, 2015). Moreover, sex before marriage has become a norm in African youths because adolescents perceive that it confirms their freedom and give privileges (Mashua, 2011). Similarly, a substantial proportion of school adolescents in Ethiopia were engaged in different risky sexual practices that are verified by the existence of multiple sexual partners and sex without condom that predispose them for sexual transmitted infections (Legesse, 2014). Adolescent childbearing and its harmful consequences for the health of both adolescent girls and the children is another dimension that has been strongly linked to premarital sexual intercourse that reflects broader forms of social and economic marginalization of girls (MDG Report, 2015).

Due to rapid globalization and availability of mass Medias, youths today have different exposures. University students in particular are suddenly exposed to a liberal environment and are free from parental control. Also, as they are in a phase where they are more prone to taking risks and exploring their sexuality, it may put them at risk of unwanted pregnancies and sexually transmitted diseases (STIs) (Mehra, 2013). Each student comes to the universities and colleges with his/her own socio-cultural background. Because of the multi ethnic and social nature of higher education institutions, they have the chance of learning malpractice in the process of daily association including risky sexual practices (Abdullahi and Umar, 2013). For the reason that students are relatively detached from familial supervision in the higher education centers, they have the opportunity to build their own way of life. Unfortunately, they are forced into risky sexual practices by their peers or adults in the campus (Kroone, 2010).

Alcoholic beverages and unsafe sex contribute to the global burden of disease, furthermore, amplified through the linkages that have been shown to exist between alcohol, risky sexual behavior and the spread of 
sexually transmitted infections (STIs). Sexual risk behavior accounts for a large number of opportunities for acquiring HIV infection, and alcohol use has been shown to increase high-risk sexual behavior (WHO, 2006). A study in Maiduguri, Nigeria showed that students were 2.5 times more likely to engage in premarital sex than other community parts. Various drugs were used by students for enhancing sexual practice which made them drug addicts. In some cases students take drugs after their relationship has broken to forget anxiety (Bukar et al, 2013). Similar finding was produced by Basel in Nepal, where one fifth of college youths had risky premarital sex where substance users had higher risky sex than non-users (Basel, 2013). Substance misuse is the main reason for risky sexual intercourse which currently becoming a growing problem in Ethiopia. Use of khat, alcohol and cigarette was significantly and independently associated with risky sexual activities (Derese et al., 2014).

Despite the fast growth of college population in Ethiopia, little has been known about risky sexual behaviors of these sexually active groups. Even though a few academic studies were conducted, there are significant inter- and intra-regional variations on the result (Legesse, 2014; Seme and Wirtu, 2006; Mbelle et al., 2014). There are now many students enrolled in higher education centers, those students should be helped to set proper norms of behavior for our society and serve as role models for younger students, that college students are establishing and solidifying lifestyles and behaviors that will stay with them for the rest of their lives. Hence, a location specific identification of risky sexual behavior of students is critical because sexual and reproductive health of students affects not only their academic achievement but also the overall health of our society.

The prevalence of premarital sex among students in the study area is worrisome because many cases of unwanted pregnancies and induced abortion were frequently happened. Additionally, sexual assault and dating activities were commonly observed in the campus. In addition, Alage is a very wide college and large numbers of local peoples are living within its province and this may expose students for risky sexual practices. Studies on the subject of premarital sex and its associated factors are not common in higher education institutions in Ethiopia, particularly in the study area. Hence, this study will try to fill the knowledge gap through revealing the extent of premarital sex and its various associated factors among students at Alage ATVET College.

\section{METHODS}

The study was conducted at Alage ATVET College which is one of agricultural technical vocational educational training college (ATVET), established under the Ministry of Agriculture, Ethiopia. It is located $217 \mathrm{~km}$ south of Addis Ababa, the capital city of Ethiopia. A cross-sectional study design was conducted to convey original quantitative and qualitative data among Alage ATVET College students. The study was adopted both the qualitative and quantitative research techniques. The quantitative and qualitative research instruments were designed in such a way that they complement each other.

Data require for the study was collected from both primary and secondary sources. The primary sources includes self-administered questionnaires, focus group discussion and key informant interview while the secondary sources looked at review of previous researches and other documents related to the topic. A structured self-administered questionnaire was prepared according to each particular objective. It was pretested on 15 students for consistency of the questions one week prior to the actual data collection. Six diploma holder data collectors and three facilitators who were disaggregated in gender were participated in data collection process.

To supplement the quantitative findings, six focus group discussion sessions (made up of 8 members in each group) were carried out. Focus group discussants were purposively drawn from campus discipline committee, students' council and gender clubs based on their intimacy in observing students while involved in risky sexual behavior. The number of male and female discussants was equal and totally 48 discussants were participated. Guideline was developed for the key informants and obtained some general information about the prevalence of premarital sex and its contributing factors. The key informants constituted: member of students' dean $(n=1)$, male and female teachers $(n=3)$, health workers $(n=1)$, proctors $(n=2)$, representatives of religious affairs $(n=3)$ and campus security guards $(n=1)$. Totally 11 key informants were selected purposively through familiarization and recommendation.

A probability sampling method was used to select target respondents among regular senior students at Alage ATVET College. Firstly, all students were clustered in to two by year of study like second year and third year students. Then students were further stratified based on their departments. All senior students at any age group, which are 2607 in number, were considered as a study population. Out of these, systematic random sampling technique was used to draw samples from each of the respective academic years and departments. 


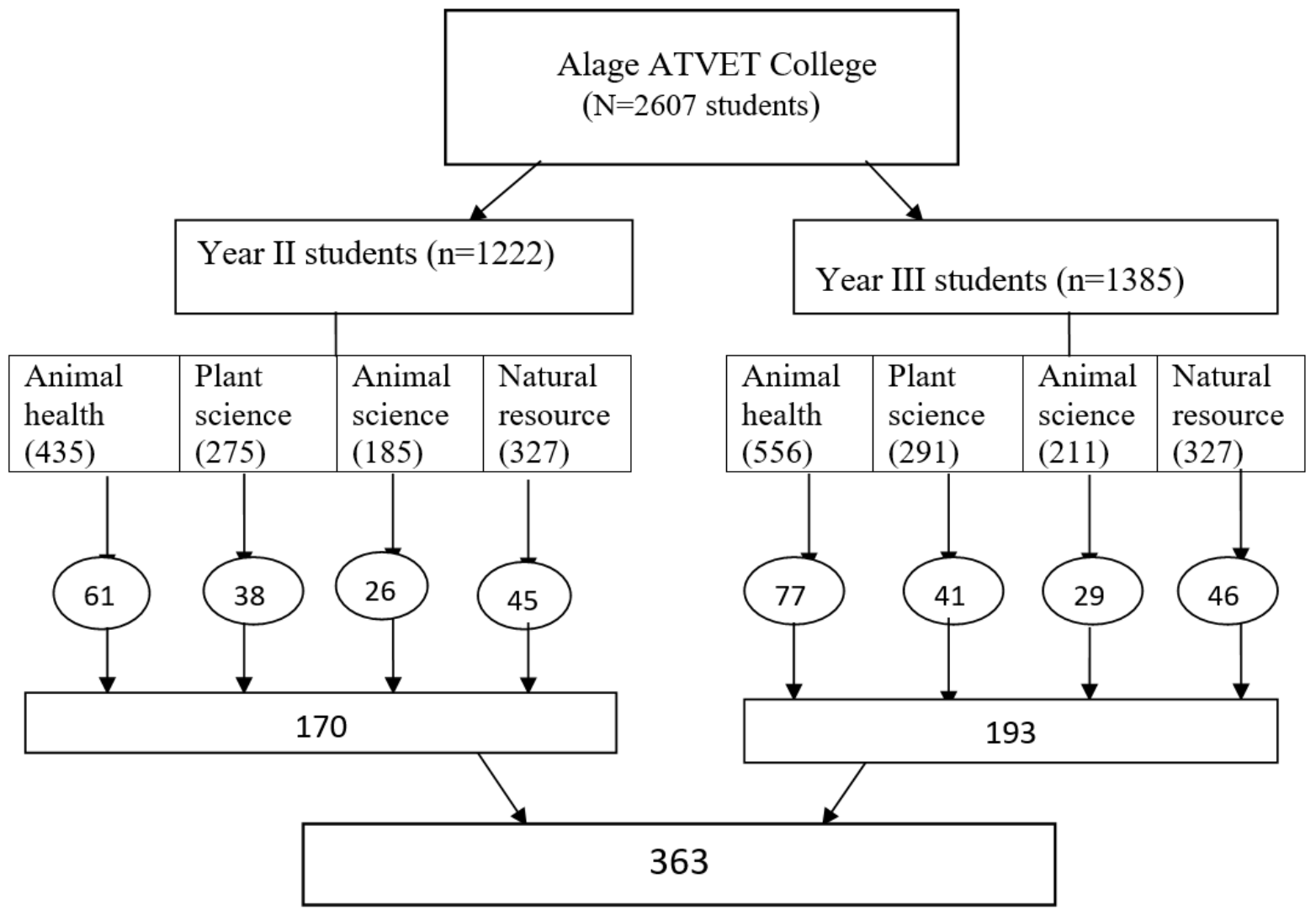

Figure 3: Schematic presentation of sampling procedure of students at Alage ATVET College, Ethiopia, 2016.

The number of year II and year III students in four departments were 1222 and 1385 respectively. Of which, 170 students from second year and 193 students from third year were selected as respondents proportionate to sample size across each department. The sample size was determined by using a simple population proportion formula. The degree of precision was assumed to be $50 \%, 95 \%$ confidence level $(\mathrm{z}=1.96), 5 \%$ marginal error $(\mathrm{d}=0.05)$ and added non-response rate of $10 \%$. Then:-

$\mathrm{n}=\mathrm{Z}^{2} \mathrm{p}(1-\mathrm{p}) / \mathrm{d}^{2}=[(1.96) 2(.5)(.5)] / .05=384.16$. Added $10 \%$ non-response rate, $=384.16+10 \%=423$. But since the total population was less than 10,000 or $\mathrm{n} / \mathrm{N}>10 \%$ it is essential to use population correction (Teklemariam, 2013).

There for, final sample size $(\mathrm{n})=\mathrm{ni} / 1+\mathrm{ni} / \mathrm{N}=423 / 1+423 / 2607=363$.

\section{Data analysis}

The collected raw data was edited, coded and entered into statistical package for social sciences (SPSS) version 20. Further cleaning and checking for missing values and errors were made after entry. Then, frequency distribution and percentages of different variables were computed and the results were illustrated in the form of frequency tables, pie charts and graphs in order to give a quick glance of the variables.

In case of inferential analysis, Bivariate and Multivariate analysis by using logistic regression models were used to determine the association between predictor variables with the dependent variable. First the relation between each independent variable and outcome variable were investigated by using a binary logistic regression analysis. The variables which showed significant association on bi-variant analysis with $\mathrm{p}$-value of $<0.05$ were used for multivariate logistic regression to minimize the effect of confounding variables and to come up with major factors of premarital sexual practices. To assess the strength of relationships between dependent and independent variables, adjusted odd ratios with $95 \%$ confidence intervals and statistical significance at $\mathrm{P}<0.05$ were declared.

\section{RESULT}

\subsection{Socio-demographic characteristics of the study participants}

Three hundred fifty five (355) students out of the total 363 samples were completed the questionnaires and making the response rate of $97.8 \%$. Eight questionnaires $(2.2 \%)$ were disregarded due to incompleteness. Therefore, 355 completed questionnaires included in the analysis. Among those participants, $132(37.2 \%)$ and 
$223(62.8 \%)$ were females and males, respectively. More than three fourth of the respondents $(80 \%)$ were in the age group of 19-24 years whereas the remaining $15(4.2 \%)$ and $56(15.8 \%)$ respondents were in the age group of $\leq 18$ years and $\geq 25$ years age respectively. The minimum age for both male and female respondents was 18 years while the maximum age for females was 27 years and that of male was 45 years. The mean (SD) age of respondents was $21.78( \pm 3.19)$ and that of females and males were $20.84( \pm 2.13)$ and $22.34( \pm 3.56)$ respectively (See table 1 below).

With regard to religion dominancy, $208(58.6 \%)$ and $78(22 \%)$ respondents were followers of Orthodox Christian and Islam respectively. A large majority of the respondents 250 (70.4\%), out of those more than half $158(63.2 \%)$ males and $92(36.8 \%)$ of females attend religious education. Moreover, this study indicated that 126(35.5\%), $98(27.6 \%), 38(10.7 \%)$, and 93 (26.2\%) of respondents were visiting religious institutions daily, once a week, once a month and never visited religious institutions respectively. The predominant ethnic group in the study area was Oromo which accounted 178 (50.1\%) followed by Sidama 80 (22.5\%), Amhara 48(13.5\%) and Tigray 39(11\%) (See table 1 below). The previous residence for the majority $198(55.8 \%)$ of respondents was rural setting and the rest 157 (44.2\%) were urban dwellers. A large majority of respondents 333 (93.8\%) were never married and less than half of the respondents $160(45.1 \%)$ reported that they get a regular pocket money from their parents (See table 1 below).

Table 1: Socio-demographic characteristics of the respondents ( $\mathrm{n}=355)$, Alage ATVET College, Ethiopia, 2016.

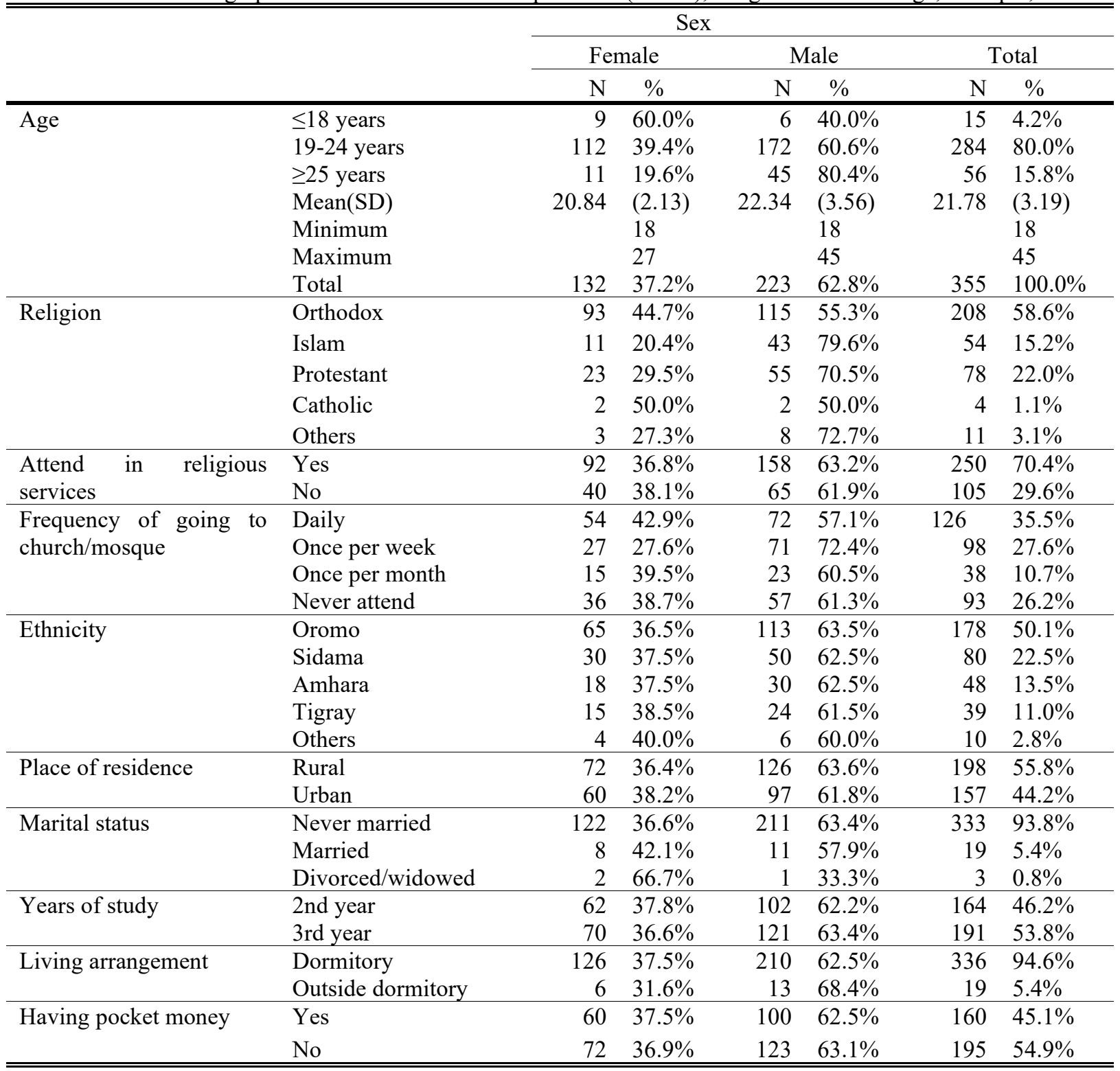

\subsection{Sexual history of respondents}

Out of the total 355 respondents, two hundred three (57.2\%) were had at least one boy/girl friends in their life 
time and one hundred ninety six $(55.2 \%)$ reported of ever having dating experience. One hundred eighty eight $(53 \%)$ respondents had premarital sexual intercourse. The mean (SD) age of all of sexually experienced respondents at first sexual intercourse was $17.8( \pm 2.21)$ years. From all sexually active adolescents, three $(37.5 \%)$ of males and $5(62.5 \%)$ of females had their first sexual intercourse before the age of 15 years (See table 3 below).

In terms of sexual partners of respondents, the majority $129(68.6 \%)$ of sexually experienced students had their first sexual intercourse with their girlfriends/ boyfriends whereas 46(24.5\%) respondents had sex with stranger, $7(3.7 \%)$ of males with commercial sex workers and $6(3.2 \%)$ of females had their first sex with their teachers. About seventeen $(9.0 \%)$ respondents reported that their first sexual partners had been younger whereas forty four $(23.4 \%)$ respondents were conducted first sex with older partners (See table 3 below). When the respondents were asked on the number of life time sexual partners they ever had, the majority $118(62.5 \%)$ reported that they had only one sexual partner while $34(18.1 \%), 16(8.5 \%)$ and $20(10.6 \%)$ reported having had two, three, and four \& above sexual partners respectively. From the total 188 premarital sexual experienced respondents, nearly three forth $(74.5 \%)$ of them had their first sexual intercourse before joining the college (See table 3 below).

Table 2: Premarital sexual history among Alage ATVET College students, Ethiopia, 2016.

\begin{tabular}{|c|c|c|c|c|c|c|c|}
\hline & & \multicolumn{6}{|c|}{ Sex } \\
\hline & & \multicolumn{2}{|r|}{ Female } & \multicolumn{2}{|r|}{ Male } & \multicolumn{2}{|c|}{ Total } \\
\hline & & $\mathrm{N}$ & $\%$ & $\mathrm{~N}$ & $\%$ & $\mathrm{~N}$ & $\%$ \\
\hline \multirow{2}{*}{$\begin{array}{l}\text { Ever had boy/girl } \\
\text { Friend }\end{array}$} & Yes & 75 & $36.9 \%$ & 128 & $63.1 \%$ & 203 & $57.2 \%$ \\
\hline & No & 57 & $37.5 \%$ & 95 & $62.5 \%$ & 152 & $42.8 \%$ \\
\hline \multirow[t]{2}{*}{ Dating Experience } & Yes & 64 & $32.7 \%$ & 132 & $67.3 \%$ & 196 & $55.2 \%$ \\
\hline & No & 68 & $42.8 \%$ & 91 & $57.2 \%$ & 159 & $44.8 \%$ \\
\hline \multirow[t]{2}{*}{ Premarital sex } & Yes & 57 & $30.3 \%$ & 131 & $69.7 \%$ & 188 & $53.0 \%$ \\
\hline & No & 75 & $44.9 \%$ & 92 & $55.1 \%$ & 167 & $47.0 \%$ \\
\hline \multirow{4}{*}{$\begin{array}{l}\text { With whom } 1 \text { st sex } \\
\text { was made }\end{array}$} & Boy/girl friend & 37 & $28.7 \%$ & 92 & $71.3 \%$ & 129 & $68.6 \%$ \\
\hline & Non-regular partner & 14 & $30.4 \%$ & 32 & $69.6 \%$ & 46 & $24.5 \%$ \\
\hline & Teacher & 6 & $100.0 \%$ & 0 & $0.0 \%$ & 6 & $3.2 \%$ \\
\hline & Commercial sex work & 0 & $0.0 \%$ & 7 & $100 \%$ & 7 & $3.7 \%$ \\
\hline \multirow[t]{6}{*}{ Age at first sex } & $<15$ years & 5 & $62.5 \%$ & 3 & $37.5 \%$ & 8 & $4.3 \%$ \\
\hline & $15-18$ years & 38 & $34.2 \%$ & 73 & $65.8 \%$ & 111 & $59.0 \%$ \\
\hline & $>18$ years & 14 & $20.3 \%$ & 55 & $79.7 \%$ & 69 & $36.7 \%$ \\
\hline & Mean(SD) & 17.1 & $( \pm 2.17)$ & 18.12 & $( \pm 2.16)$ & 17.8 & $( \pm 2.21)$ \\
\hline & Minimum & & 12 & & 13 & & 12 \\
\hline & Maximum & & 22 & & 24 & & 24 \\
\hline \multirow[t]{2}{*}{ When was first sex } & Before college & 43 & $30.7 \%$ & 97 & $69.3 \%$ & 140 & $74.5 \%$ \\
\hline & In the college & 14 & $29.2 \%$ & 34 & $70.8 \%$ & 48 & $25.5 \%$ \\
\hline \multirow{2}{*}{$\begin{array}{ll}\text { Condom } & \text { used } \\
\text { during } 1^{\text {st }} \text { sex } & \end{array}$} & Yes & 35 & $31.8 \%$ & 75 & $68.2 \%$ & 110 & $58.5 \%$ \\
\hline & No & 22 & $28.2 \%$ & 56 & $71.8 \%$ & 78 & $41.5 \%$ \\
\hline \multirow{4}{*}{$\begin{array}{l}\text { Number of sexual } \\
\text { partner so far }\end{array}$} & One & 43 & $36.4 \%$ & 75 & $63.6 \%$ & 118 & $62.8 \%$ \\
\hline & Two & 5 & $14.7 \%$ & 29 & $85.3 \%$ & 34 & $18.1 \%$ \\
\hline & Three & 3 & $18.8 \%$ & 13 & $81.3 \%$ & 16 & $8.5 \%$ \\
\hline & Four and above & 6 & $30.0 \%$ & 14 & $70.0 \%$ & 20 & $10.6 \%$ \\
\hline
\end{tabular}




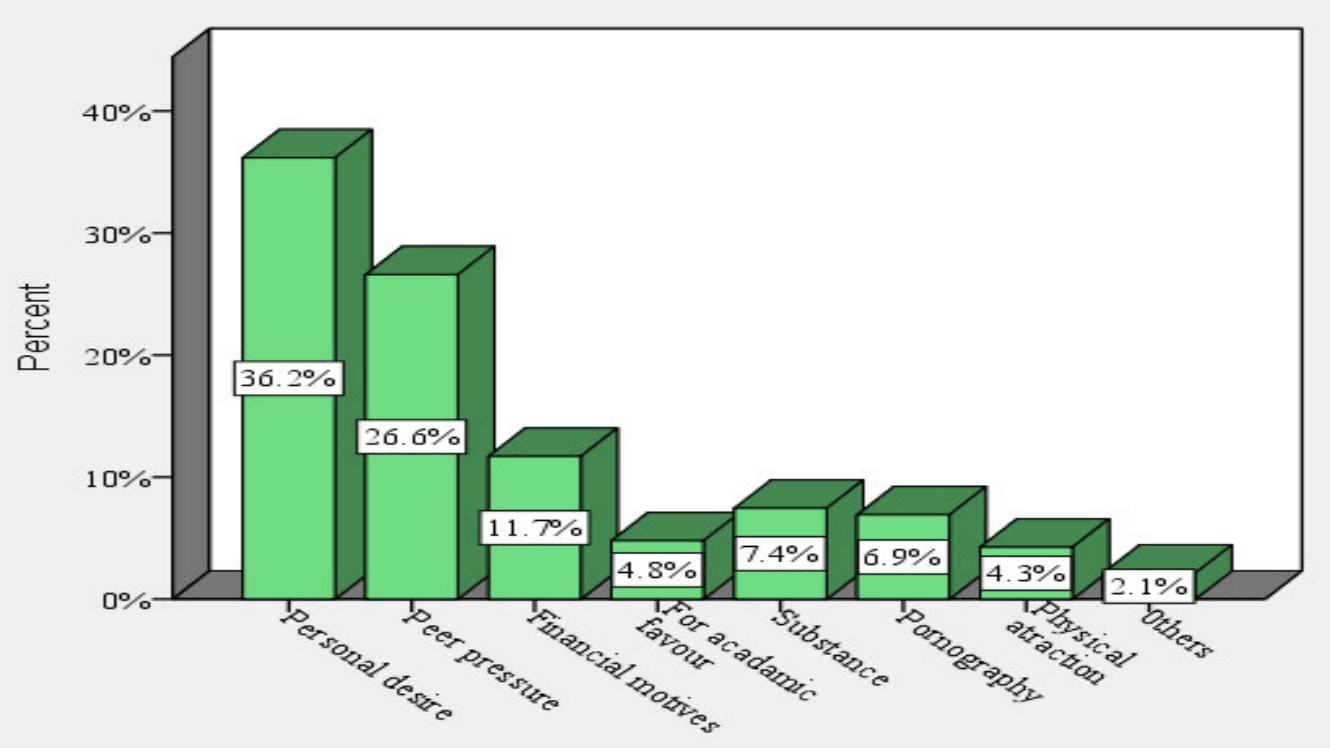

Figure 2: Main reasons for having premarital sexual intercourse among Alage ATVET College students, Ethiopia, 2016.

As presented by the figure above, the main reasons for initiation of premarital sexual intercourse were related to personal interest/curiosity $(36.2 \%)$, peer pressure $(26.6 \%)$, financial motives $(11.7 \%)$, substance influence $(7.45 \%)$, influence of pornographic movies $(6.9 \%)$, for academic favor $(4.8 \%)$, physical attraction of opposite sex (4.3\%) and other reasons $(2.1 \%)$ (See figure 4$)$.

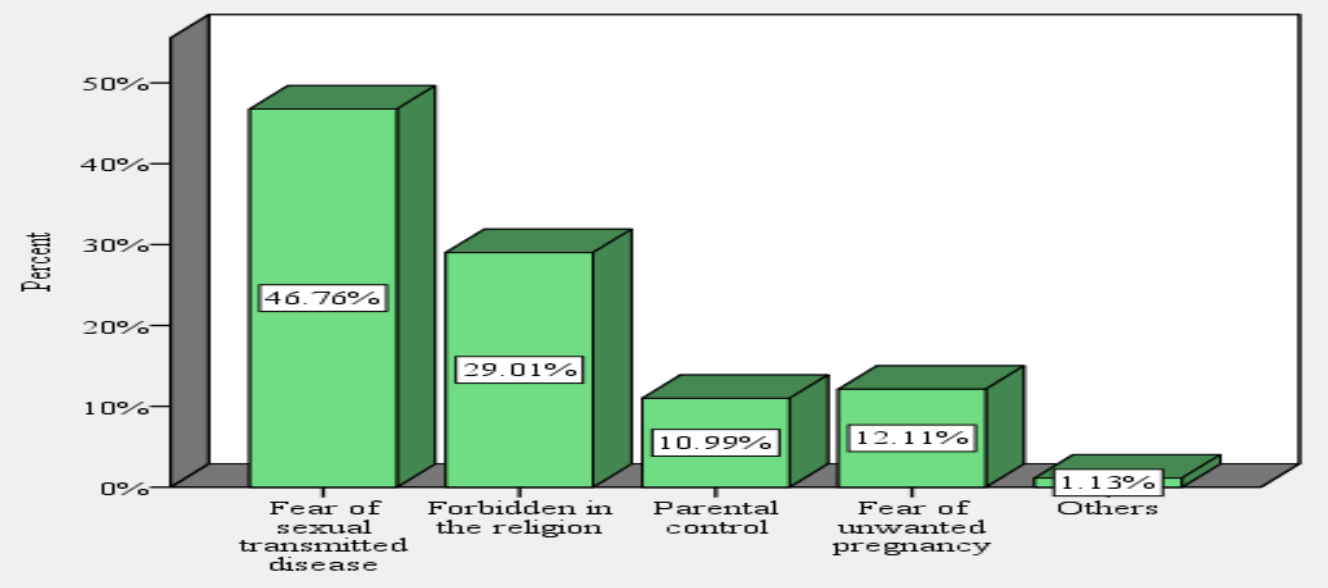

Figure 3: Perceived protective factors that help to delay the onset of sexual intercourse among Alage ATVET college students, Ministry of Agriculture and Natural Resource, Ethiopia, 2016.

The participants of this study reason out the protective factors that refrain them from commencing premarital sexual intercourse. As figure five depicted here above, young people's care-seeking behavior (fear of sexual transmitted disease) $(46.76 \%)$ was the main protective reason for not starting premarital sexual intercourse followed by religious value(religiosity) $(29.01 \%)$, parental control $(10.99 \%)$, fear of unwanted pregnancy $(12.11 \%)$ and other reasons (1.13\%) respectively (See figure 5 above). In the qualitative study, religion was repeatedly mentioned as a shield to avoid premarital sexual intercourse. Premarital sex was considered as a serious sin based on religious beliefs of participants. For example, a 24 year old male participant stated in this regard: "Religious beliefs are very important to restrain youths from risky behaviors because religious leaders preach daily against what is called bad behaviors like corruption, alcoholism, and sexual intercourse before marriage. Someone who really adhere to his/her religion will never experience premarital sexual intercourse, and if he/she have sex, it is adultery, sin and prohibited in the religion of Christianity and Islam".

\subsection{Current sexual experience of students}

Out of $188(53 \%)$ ever sexual experienced respondents, one hundred fifty six $(83 \%)$ of them had sexual 
intercourse during the previous 12 months prior to the survey. Among these, $111(71.2 \%)$ and $45(28.8 \%)$ were males and females respectively. When respondents were asked about the number of sexual partners they had, the majority $131(84 \%)$ of them reported that they had only one sexual partner in the past 12 months prior to the survey (See table 4 below). Among sexual experienced students in the past 12 months (156), about (78.2\%) of them had sexual intercourse with their girlfriends/ boyfriends while $15(9.6 \%)$ with stranger, 12(7.7\%) of males with commercial sex workers and $7(4.5 \%)$ of female students had sexual intercourse with their teachers. Another typical feature that makes youth sexual activity risky is the absence or incorrect use of condom during sexual intercourse. Accordingly, out of 188 ever sexually experienced students, only 133 (70.7\%) students were never used condoms during their last sexual intercourse (See table 4 below).

Table 3: Current sexual experience among Alage ATVET College students, Ethiopia, 2016.

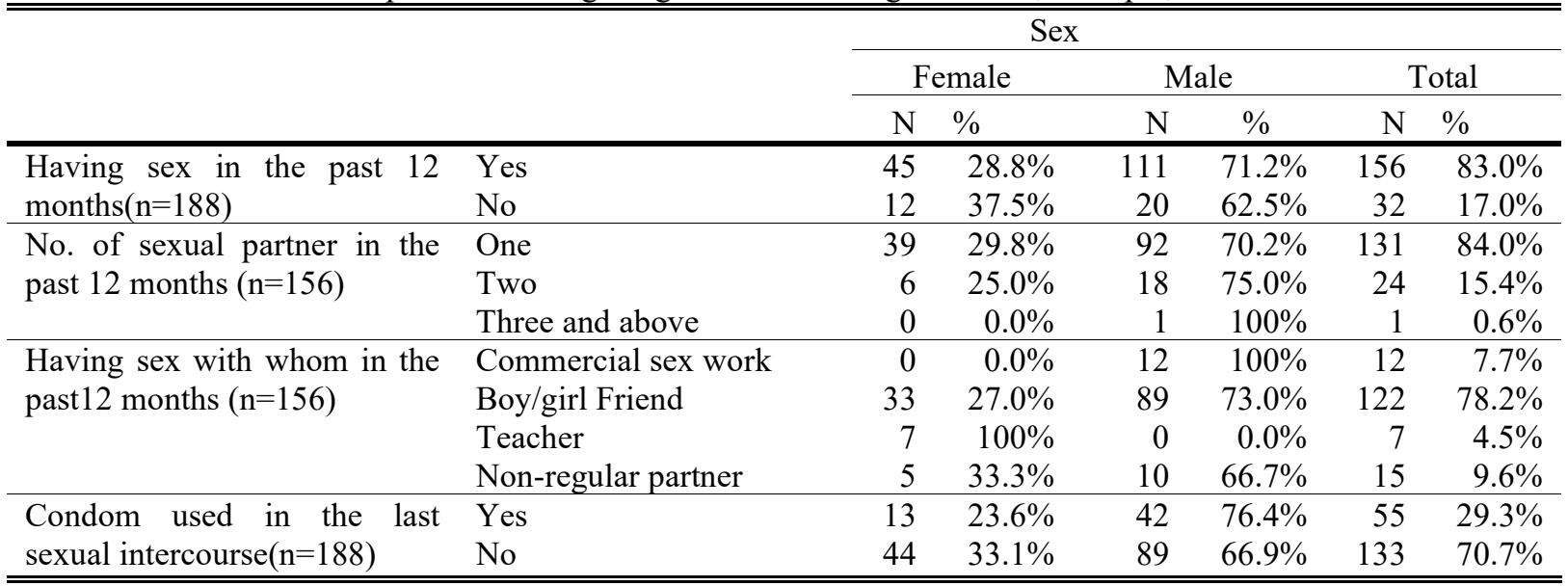

\subsection{Communication with parents and source of knowledge about sexuality.}

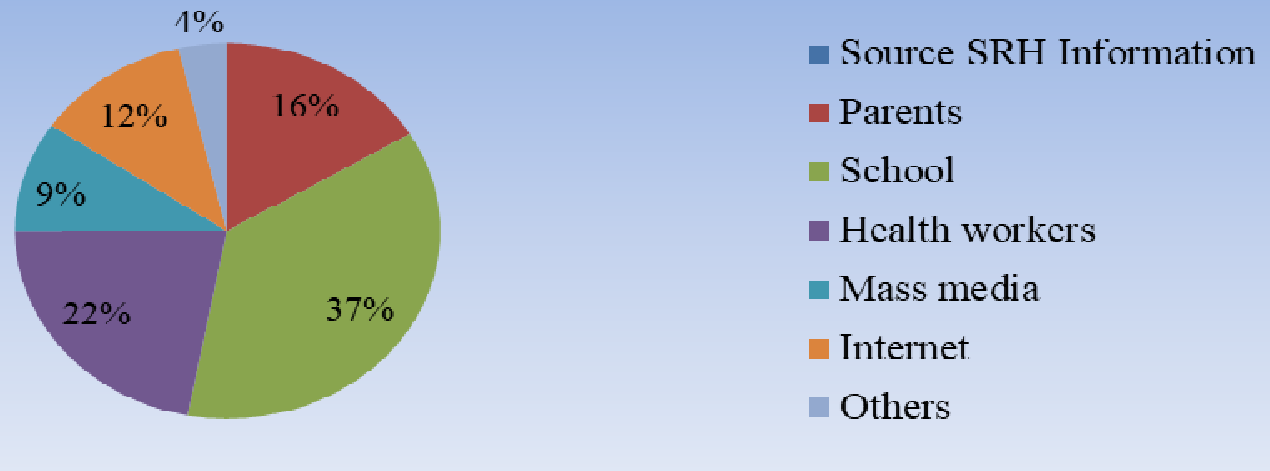

Figure 4: Sources of sexual and reproductive health information among students of Alage ATVET College, Ministry of Agriculture and Natural Resource, Ethiopia, 2016.

One alarming finding in this particular study is that a higher proportion of respondents $(37 \%)$ were acquired knowledge about sexual and reproductive health issues from school, followed by health workers $(22 \%)$, parents $(16 \%)$, internet (12\%), mass media (radio, TV) $(9 \%)$ and others sources (4\%) (See figure 6 above). From this we can deduce that, sexual and reproductive health intervention, particularly in colleges and universities, should be provide adequate, consistent, need based and clear messages to equip youths with necessary knowledge and skills to bring the desire behavioral change.

\subsection{Main risky behaviors related to pre-marital sexual practices}

Out of the total 355 respondents $106(29.9 \%)$ were reported to have sexual experienced friends and of which 75 $(70.8 \%)$ and $31(29.2 \%)$ were males and females respectively. Among all participates in the quantitative study, one hundred twenty one (34.1\%) of which $100(82.6 \%)$ males and $21(17.4 \%)$ females reported that they had watched pornographic movies at list once in their life. The majority of the study participants, who were involved in the focus group discussion also argued that," Nowadays, both male and female students use media and films to pass their time. Males and females see pornographic videos and it really encourages them to do that in real life. So they have premarital sex "(FGD, 21 year female student).

The study revealed that $52(14.6 \%)$ of the students were chewed khat at least once in their lifetime. Regarding to alcohol drinking habits of respondents, $148(41.7 \%)$ reported that they drank alcohol at least once 
in their lifetime. Accordingly only 18 (5.1\%) respondents used cigarette. Overall one hundred eighteen $(66.7 \%)$ and $59(33.3 \%)$ of the respondents were started to consume substances before and after joining to the college respectively (See table 6 below).

Table 4: Main risky behaviors related to premarital sexual practices among Alage ATVET College Students, Ministry of Agriculture and Natural Resource, Ethiopia, 2016.

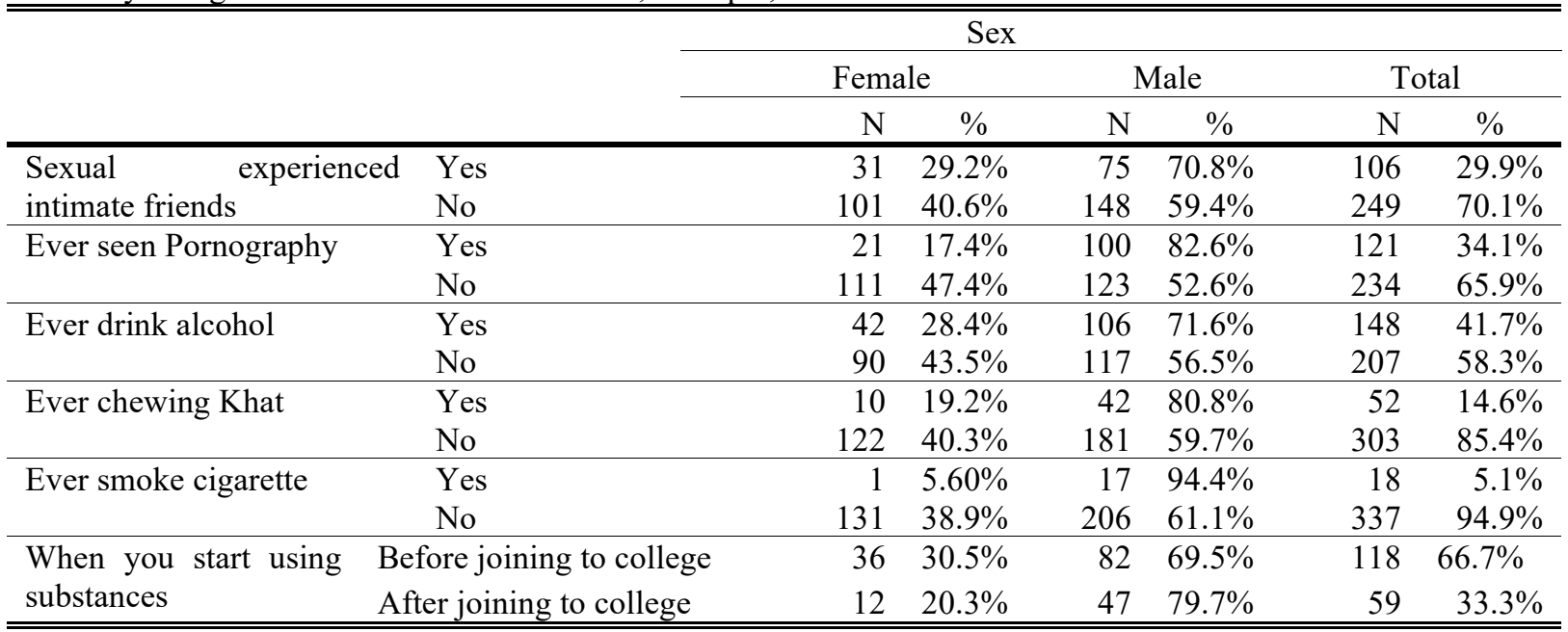

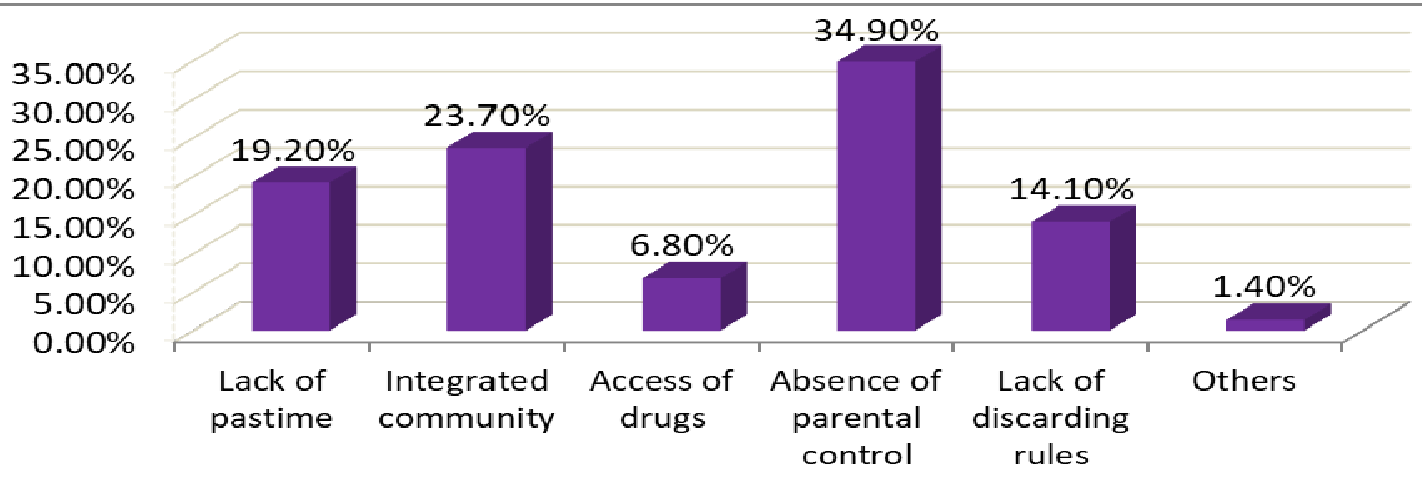

Figure 5: Perceived driving factors for premarital sexual intercourse associated with school environment at Alage ATVET College, Ethiopia, 2016.

Regarding to the reasons for initiation of premarital sex associated with school environment, the respondents claimed major reasons were; absence of parental control (supervision) (34.9\%) followed by integrated local community in the college (23.7\%), lack of pastime/entertainment (19.2\%), lack of discarding rules/lack of rules regulating risky sexual intercourse $(14.1 \%)$, high access of drugs $(6.8 \%)$ and other factors within the college (1.4\%) (See figure 7 above). Almost the entire focused group discussants also suggest that the prevalence of premarital sex at Alage ATVET College is more severe than elsewhere because of the availability of substance, peer pressure and school environment. For instance, a 25 years female student opined that "Dating is the most common practice and becoming as a fashion compared to penetrative sexual activities. It is the act of kissing, fondling, placed hands on girl's breast to sexual stimulation. There is a high chance of sexual acts occurring if students arrange a date at a sheltered and quiet place."

\subsection{Factors associated with premarital sex at bivariate and multivariate logistic regression analysis}

Among the socio-demographic variables, family income and knowledge about SRH issues, and from the behavioral variables such as, chewing khat were associated with pre-marital sexual practice only at COR at $\mathrm{p}$ $<0.05$ while other variables like male sex, having regular pocket money, ever having boy/girl-friend, ever having dating experience, ever had sexual experienced intimate friends, frequency of visiting religious institutions, ever watched pornography and ever drink alcohol were all significantly associated with pre-marital sexual practice at both crude and adjusted odd ratios at $\mathrm{p}<0.05$ (See table 7 below). Male respondents were more than three times to have pre-marital sexual practice as compared to female respondents $[\mathrm{AOR}=3.33$, 95\% CI (1.2-9.24)]. Regarding to participation in religious services, students who visit religious institutions daily were sixty six percent less likely to be engaged in premarital sexual intercourse when compared to those who did not 
visit $[\mathrm{AOR}=0.66,95 \% \mathrm{CI}(0.22-2.04)]$. Respondents who had pocket money found to be more than nine times more likely practiced premarital sex than those did not have [AOR=9.63, 95\% CI (3.61-25.79)] (See table 7 below). Adolescents who had boy or girl friends were almost forty two times more likely practiced premarital sex $[\mathrm{AOR}=41.92,95 \%$ CI (14.07-124.88)] compared with those who had no boy or girl friends. Similarly, students who have an intimate friend who started sex were about three times more likely to have pre-marital sexual intercourse compared to those who do not have [AOR $=2.97 ; 95 \%$ CI: (1.06-8.32)] (See table 7 below). Those students who were watching pornography movies were [AOR=1.34, 95\% CI (0.45-3.98)] 1.34 times more likely practiced premarital sex compared to those didn't watch pornography, and there is also statistically significant association between alcohol intake and having premarital sexual intercourse $[\mathrm{AOR}=1.54 ; 95 \% \mathrm{CI}$ : (0.59-4.01)] (See table 7).

Table 5: Factors associated with premarital sexual practices at bivariate and multivariate logistic regression analysis for Alage ATVET College students, MANR, Ethiopia, 2016.

\begin{tabular}{|c|c|c|c|c|c|c|}
\hline \multirow{2}{*}{ Sex } & \multicolumn{4}{|c|}{ Premarital sex ever practiced } & \multirow{2}{*}{$\begin{array}{l}\text { COR } \\
\quad(95 \% \mathrm{CI}) \\
\end{array}$} & \multirow{2}{*}{$\begin{array}{l}\text { AOR } \\
(95 \% \mathrm{CI})\end{array}$} \\
\hline & \multicolumn{2}{|c|}{ Yes } & \multicolumn{2}{|c|}{ No } & & \\
\hline Female & 57 & $30.3 \%$ & 75 & $44.9 \%$ & 1 & 1 \\
\hline Male & 131 & $69.7 \%$ & 92 & $55.1 \%$ & $1.87(1.20-2.90)$ & $3.33(1.2-9.24) *$ \\
\hline \multicolumn{7}{|c|}{ Frequency of visiting religious institutions } \\
\hline Daily & 53 & $28.2 \%$ & 73 & $43.7 \%$ & 1 & 1 \\
\hline Once per week & 63 & $33.5 \%$ & 35 & $21.0 \%$ & $0.40(0.23-0.70)$ & $0.58(0.18-1.93) *$ \\
\hline Once per month & 26 & $13.8 \%$ & 12 & $7.20 \%$ & $0.33(0.15-0.72)$ & $0.36(0.07-2.0)$ \\
\hline Never attend & 46 & $24.5 \%$ & 47 & $28.1 \%$ & $0.74(0.43-1.27)$ & $0.66(0.22-2.0) * *$ \\
\hline \multicolumn{7}{|c|}{ Having pocket money } \\
\hline Yes & 115 & $61.2 \%$ & 45 & $26.9 \%$ & 1 & 1 \\
\hline No & 73 & $38.8 \%$ & 122 & $73.1 \%$ & $4.27(2.72,6.70)$ & $9.63(3.61-25.79)^{* * *}$ \\
\hline \multicolumn{7}{|c|}{ Family income per month } \\
\hline$\leq 500 \mathrm{ETB}$ & 64 & $34.0 \%$ & 75 & $44.9 \%$ & 1 & 1 \\
\hline 500-1000 ЕТВ & 47 & $25.0 \%$ & 49 & $29.3 \%$ & $0.84(0.51-1.43)$ & $0.68(0.23-2.04)$ \\
\hline 1001-1500 ЕТВ & 34 & $18.1 \%$ & 16 & $9.60 \%$ & $0.39(0.20-0.76)$ & $0.27(0.07-1.02)$ \\
\hline$\geq 1500$ ETB & 17 & $9.0 \%$ & 7 & $4.20 \%$ & $0.38(0.15-0.92)$ & $0.19(.031-1.14)$ \\
\hline I do not know & 26 & $13.8 \%$ & 20 & $12.0 \%$ & $0.78(0.40-1.50)$ & $0.40(0.09-1.78)$ \\
\hline \multicolumn{7}{|c|}{ Ever had boy/girl friend } \\
\hline Yes & 169 & $89.9 \%$ & 34 & $20.4 \%$ & 1 & 1 \\
\hline No & 19 & $10.1 \%$ & 133 & $79.6 \%$ & $34.8(18.99-63.76)$ & $41.9(14.07-124) * * *$ \\
\hline \multicolumn{7}{|l|}{ Dating experience } \\
\hline Yes & 160 & $85.1 \%$ & 36 & $21.6 \%$ & 1 & 1 \\
\hline No & 28 & $14.9 \%$ & 131 & $78.4 \%$ & $20.8(12.06-35.87)$ & $42.4(14.9-120.6)^{* * *}$ \\
\hline \multicolumn{7}{|c|}{ Having sexual experienced close friends } \\
\hline Yes & 66 & $35.1 \%$ & 40 & $24.0 \%$ & 1 & 1 \\
\hline No & 122 & $64.9 \%$ & 127 & $76.0 \%$ & $1.72(1.08-2.73)$ & $2.97(1.06-8.32)^{*}$ \\
\hline \multicolumn{7}{|c|}{ Knowledge about SHR issues } \\
\hline Poor & 74 & $39.4 \%$ & 49 & $29.3 \%$ & 1 & 1 \\
\hline Medium & 94 & $50.0 \%$ & 78 & $46.7 \%$ & $1.25(0.78-21)$ & $1.81(0.66-4.98)$ \\
\hline Good & 20 & $10.6 \%$ & 40 & $24.0 \%$ & $3.02(1.58-5.8)$ & $11.49(2.47-53.53)$ \\
\hline \multicolumn{7}{|c|}{ Ever seen pornography } \\
\hline Yes & 80 & $42.6 \%$ & 41 & $24.6 \%$ & 1 & 1 \\
\hline No & 108 & $57.4 \%$ & 126 & $75.4 \%$ & $2.28(1.44-3.59)$ & $1.34(0.45-3.98) *$ \\
\hline \multicolumn{7}{|l|}{ Ever drink alcohol } \\
\hline Yes & 92 & $48.9 \%$ & 56 & $33.5 \%$ & 1 & 1 \\
\hline No & 96 & $51.1 \%$ & 111 & $66.5 \%$ & $1.9(1.24-2.92)$ & $1.54(0.59-4.01) * *$ \\
\hline \multicolumn{7}{|l|}{ Ever chewing khat } \\
\hline Yes & 41 & $21.8 \%$ & 11 & $6.60 \%$ & 1 & 1 \\
\hline No & 147 & $78.2 \%$ & 156 & $93.4 \%$ & $3.96(1.96-7.99)$ & $5.13(0.98-26.81)$ \\
\hline
\end{tabular}




\section{Discussion}

This study investigated the prevalence of premarital sexual practices and associated factors among senior students in Alage ATVET College, Ministry of Agriculture and Natural Resource, Ethiopia. The overall prevalence of premarital sexual practice in the study population was $188(53 \%)$. This finding is higher than the findings reported for Shendi town which was 157 (19\%), kolfe keraniyo sub city (19.8\%) and Jimma Teacher Training College 142 (39.7\%) (Bogale and Seme, 2014; Alemu et al., 2015 \& Fekecha et al., 2014). Similarly half of students of Wollega University had premarital sex (Legesse, 2014). The current finding is however; lower than 60.9\% reported in Alkan University College in Addis Ababa (Gemechu, 2014). In Uganda, the figures were higher than the current finding, which were $60.3 \%$ (Mehra. 2013). It opposed to a study in Mashhad university of Iran on which only $15 \%$ of students engaged in premarital sex in their life time (Reza et al., 2014). Hence, the prevalence of premarital sexual behavior varies across the world. The disparity may be due to different sample characteristics, different cultural background, and different socioeconomic environment as well as religious conditions.

The proportion of male students $131(69.7 \%)$ who were involved in premarital sex in the study area was more than the proportion of female students 57(30.3\%). This finding is higher than the finding of Alkan University College in Addis Ababa, in which 58\% males and 42\% of females were had premarital sex (Gemechu, 2014). This finding also corroborated with the study reported by Basel (2013) in Nepal where male was more likely $(16.9 \%)$ to be involved in premarital sex than female $(2.6 \%)$. The same is true in university of South Africa, in which 119(60.7\%) males and 77(39.3\%) females were engaged in sexual intercourse (Dekeke, 2014). In Uganda, more males (66.2\%) had premarital sex compared to females (60\%) (Mehra, 2013). This finding is also relatively high particularly for males compared to other prior findings in the Middle East. In Iran, for instance, the lifetime prevalence of sexual relationship in males $(32.9 \%)$ was significantly higher than females (7.6\%) (Reza et al., 2015).

The mean (SD) age at first sexual intercourse for both sexes was about $17.8( \pm 2.21)$ years, while $18.12( \pm 2.16)$ years for males and $17.07(( \pm 2.17)$ years for females. It is slightly greater than a study conducted in west Gojjam zone reported that the mean age at first sexual intercourse was $16.5( \pm 1.6)$ years for males and 15.9 $( \pm 1.7)$ for females and out of all sexually active youths, $20(12.7 \%)$ had their first sexual intercourse before the age of 15 years (Bogale and Seme, 2014). Another similar study carried out in Gedeo zone revealed that the mean age of sexual debut for both sexes was $16.7( \pm 2.8)$ and that of males and females were $17( \pm 3)$ and 15.7( \pm 2.1$)$ years respectively (Alemayehu, 2006). A study conducted in India (Prasad et al., 2014) showed that the mean age at first sexual practice was 18.3 years which is greater than the current study. Exactly half of students in Iran started sexual contact between the age of 15-19 years old and 24\% of them initiated at age below 15 years old (Reza et al., 2014). Generally, the age category of sexual initiation among adolescents is quite different in different study areas due to different socio-economic environments into which students were exposed.

When the partners of the respondents during their first sexual intercourse were examined, the majorities of the partners (68.6\%) were boy/girl-friends followed by strangers $(24.5 \%)$ and teachers (3.2\%). According to a study from HAPCO (2014), $81 \%$ of male and $63 \%$ of female students had sex with non-regular partners (strangers). In addition among sexually active male students almost two third (64\%) had sex with female sex workers. This study also in line with another finding in the university of south Africa where (43.3\%) of sexually experienced students reported that their first sexual intercourse was with a boy or girl friend, while (4.0\%) claimed that their first sexual partner was a stranger (Dekeke,2014). This situation implies that the substantial numbers of adolescents carried out sexual intercourse with unknown person (stranger). Therefore, they have higher probability of acquiring HIV and other sexual transmitted infections.

In this study, the main reasons reported for initiation of premarital sex were personal desire to have sex 68 $(36.2 \%)$, peer pressure $50(26.6 \%)$, and to get money or gifts $22(11.7 \%)$. A quantitative study in Jimma university revealed that sexual desire $106(42.9 \%)$, peer pressure $66(26.7 \%)$ and to maintain relationship with partner 48(19.4\%) were important influencing factors of early sexual intercourse (Tura et al., 2012)). A similar study among adolescents of Kolfe Keraniyo sub city, Addis Ababa showed that main reason reported for initiation of premarital sexual practice was peer pressure which accounted 37 (30.8\%) (Alemu et al, 2015). A cross sectional study from Nekemete town indicated that, peer pressure contributes for $17.2 \%$ of pre-marital sexual initiation of the adolescents (Legesse, 2014). Likewise, according to a study conducted in Gedeo, personal desire and peer pressure were the most common reasons to commence sexual intercourse reported by $81.2 \%$ and $10.6 \%$ sexually active respondents respectively (Alemayehu, 2006). This finding is also consistent with other studies conducted in other countries. For instance, a study conducted in Nepal, curiosity, peer pressure and experience of watching pornographic films were identified as the main factors associated with premarital sex (Regmi et al., 2010). However, a study done by Abdullahi (2013) in Nigeria university of Maiduguri indicated that majority $(69 \%)$ of the respondents carried out early sexual intercourse due to economic reasons.

This study further inquired participants to point out perceived protective factors that help to delay the onset of sexual intercourse. Out of these reasons, fear of sexual transmitted disease $(46.76 \%)$ was mentioned as the 
main factor of delaying premarital sexual intercourse followed by religious value (29.01\%), parental control $(10.99 \%)$ and fear of unwanted pregnancy $(12.11 \%)$. This finding was supported by the previous study done by Gebremedhin (2015) in Mekele, where religiosity is the leading protective factor 120 (28.6\%) followed by economic problems/lack of pocket money 24(5.7\%). Similarly, a study in Iran stated that premarital sex is relatively rare, especially in Islamic societies, because sexuality is a sensitive issue for many Muslims (Ghaffari et al., 2014).

Focus group discussants also gave emphasis for perceived social benefits like keeping own honor or dignity of their families, and psychological benefits such as mental and spiritual peace. For example, a 21 year female discussant stated that: "I give a value for my parents from whatever I have in my life. So I do not want to lose my personality and my family's dignity and that is why I do not want to have premarital sexual intercourse".

In this study, some socio-demographic variables such as sex of respondents, frequency of visiting religious institutions, having pocket money, and variables from young people sexual history, such as ever had girl/boyfriend, dating experience, intimate friends had sexual experience, ever seen pornography and ever drink alcohol were analyzed for possible association with pre-marital sexual practice. Being a male adolescent was found to be significantly associated with premarital sex in the study area. Multi-variate logistic regression analysis showed that male respondents were more than 3 times to have premarital sexual intercourse as compared to female respondents $[\mathrm{AOR}=3.33,95 \% \mathrm{CI}(1.2,9.24)]$. The finding of this study was higher than the same study conducted in Harumaya university $[\mathrm{AOR}=1.89,95 \%$ CI $(1.18,3.04)]$ and lower than that of done in Alkan university college, Addis Ababa [AOR=7.6; 95\% CI (4.51, 34.87)] (Derese et al., 2014 and Gemechu, 2014).

In the current study, students who had pocket money were found to be nearly ten times more likely to practice premarital sex than those who did not have[AOR=9.63,95\%CI $(3.61,25.79)]$. This finding was supported by the study of Endazenew and Abebe (2015) in west Shewa who found that participants who have no pocket money were $86 \%$ less likely engaged in premarital sexual practice when compared to participants who have pocket money $[\mathrm{AOR}=0.14 ; 95 \%$ CI $(0.09-0.20)]$. Similarly premarital sexual practice was strongly associated with having pocket money among adolescents of Kolfe Keraniyo [AOR=3.04 95\% CI (1.6-5.78)] and Jimma $[\mathrm{AOR}=2.2,95 \%$ CI $(1.14,4.05)]$ (Alemu et al., 2015 \& Fekecha, 2013). This is also consistent with another study done in Nigeria university of Maiduguri (Abdullahi, 2013). The possible reasons might be due to lack of skills to wisely use the pocket money, students use the money for exposure to different medias that initiate sex, have high chance of dating with their friends and drinking different alcoholic beverages and buy different addictives as well as porn films that enforce them to start premarital sex (Fekecha et al., 2013 and Gebremedhin et al., 2015).

Respondents who had boy or girl friends were almost forty two times more likely practiced premarital sex [AOR $=41.92,95 \%$ CI $(14.07,124.88)$ compared with those had no boy or girl friends. This is greater than another previous findings in Nekemete Town, east Wollega [AOR=22.3, 95\% CI $(13.1,37.9)]$ (Seme and Wirtu, 2006). Those students whose close friends practiced premarital sex were [AOR=2.97, 95\% CI $(1.06,8.32)$ ] nearly three times more likely to be engaged in premarital sex compared with those adolescents whose friends didn't experience premarital sex. This finding agrees a study conducted in university of South Africa (Dekeke, 2014). Likewise, according to a study in Kolfe Keraniyo, students whose close friends practiced premarital sex were $[\mathrm{AOR}=4.52 ; 95 \% \mathrm{CI}(2.50-8.51)] 4.5$ times more likely to be engaged in premarital sex compared with those adolescents whose friends didn't experience premarital sex (Alemu et al., 2015).

According to the finding of this study, 121 (34.1\%) of respondents had watched pornographic materials. Those students who were watching pornography movies were $[\mathrm{AOR}=1.34,95 \% \mathrm{CI}(0.45,3.98)] 1.34$ times more likely practiced premarital sex compared to those didn't watch pornography film. This is relatively lower than another study in west Shewa in which students who watched pornographic movies were 4.03 times more likely involved in premarital sex when compared to students who did not watch it (Endazenew and Abebe, 2015). A study in Addis Ababa shows students who watched pornographic materials were three times more likely to engage in early sexual activity than who didn't watch(Girma et al ., 2015). This study was more consistent with a cross sectional study conducted in Shendi Town, where students who reported watching pornographic movies were about 1.7 times more likely to experience premarital sex than those who didn't (Bogale and Seme, 2014). Similar study in Jimma town reported that respondents who saw pornography were more likely to indulge in premarital sexual practice than those who didn't see it $[\mathrm{AOR}=5.7,95 \%$ CI $(2.82,11.43)]$ (Fekecha, 2013).

In this study, alcohol users were 1.5 times more likely to begin premarital sexual intercourse than those who didn't use alcohol $[\mathrm{AOR}=1.54,95 \% \mathrm{CI}(0.59,4.01)]$ and it is congruent with a study done by Derese (2014) in Harumaya university. However, lower than another study done in West Shewa which states students who drink alcohol were 2.63 times more likely involved in premarital sex when compared to students who did not drink alcohol (Endazenew and Abebe, 2015). Alcohol drinking increases the odds of risky sexual behavior with 0.47 $[\mathrm{AOR}=0.47,95 \%$ CI $(0.18,1.19)]$ (Bogale and Seme, 2014). Similarly a study in Wollega University depicted that the odd of having had sex is significantly three times higher for youths of drinking alcohol than youths who 
didn't drink (Legesse, 2014). This is comparable with a study in Nepal in which youths who drink and get involved in premarital sex behavior are much higher (34.6\%) than youths who do not drink (7.1\%) (Basel, 2013). We can generalize that substance intake was the risk factor for initiation of sexual intercourse like khat chewing and alcohol drinking. This is consistent with qualitative study in which discussants were mentioned that when boys drink, they lose their control over their sexual need and get forced to engage in sexual practice.

\section{CONCLUSION}

This study was set up to assess the level of premarital sexual practice and associated factors in Alage ATVET College, Ministry Agriculture and Natural Resource, Ethiopia. Based on the finding of both quantitative and qualitative studies premarital sex was commonly practiced by most school adolescents. One hundred eighty eight $(53 \%)$ of the participants practiced premarital sexual intercourse with one or more sexual partners in their life time. Among those sexually active respondents, sixty nine (36.7\%) and $111(59 \%)$ started sexual intercourse at the age of greater than 18 years and between $15-19$ years of age respectively. Additionally, $41.5 \%$ and $70.7 \%$ of them were not used condom during their first and last sexual intercourse respectively.

Main reasons reported for initiation of premarital sex were personal desire to have sex $(36.2 \%)$, peer pressure (26.6\%), and financial motive (to get money or gifts) $(11.7 \%)$ whereas fear of sexual transmitted disease $(46.76 \%)$, religious value $(29.01 \%)$, parental control $(10.99 \%)$, fear of unwanted pregnancy $(12.11 \%)$ were considered as main protective reasons for not starting premarital sexual intercourse. Among the sociodemographic variables, sex of the respondents (male), having regular pocket money and frequency of visiting religious institutions; and from the behavioral variables, having boy or girl friend, students who have dating experience, participants who watched pornographic movies, students whose close friends experienced in premarital sex and respondents who drink alcohol were significantly associated with pre-marital sexual practice. Therefore, school peer reproductive education should be strengthened and should provide comprehensive, accurate and timely information on sexual issues. An integrated effort between school administrative and the surrounding community need to be initiated to address adolescents' sexual and reproductive health problems through empowering females, discouraging risky sexual behaviors like the use of drugs among adolescents and watching pornographic movies that push them to engaged to sexual practice; and sensitizing parents, community members and the public focusing on parent-child communication and discussion about sex related issues.

\section{RECOMMENDATIONS}

Since the students are to be distributed in the community after completing their education, preparing and equipping them with necessary knowledge of sexual and reproductive health will help to disseminate information widely in the community in a sustainable way in addition to protecting themselves. After a thorough examination and comparison of the data obtained from both quantitative and qualitative study on the prevalence of premarital sexual practices and associated factors, the following recommendations are made.

- Algae ATVET College supposed to design programs with comprehensive education on sexual and reproductive health issues through strengthen behavioral change communications; life skill training, peereducation, and working with the surrounding community to address the accessibility of services, and provide information related to SRH issues.

- Education and health offices should work together in order to promote open discussion about sexuality and updated information related to SRH issues through school health education, establishing reproductive health club in the colleges and universities.

- There is a need for institutions of higher education to develop programs and policies that will assure a safe institutional environment and promote access to health care services and contribute to the health, well-being, and academic success of students.

- The college authority should step up to its responsibility as a guardian of students by punishing the youths who force the students to engage in risky sexual activities in the campus, and review the policy regulating the conduct of substance use and the practice of unsafe pre-marital sex.

- Strengthen cooperation between school administrative and the surrounding community to address SRH problems through discouraging risky sexual behaviors; and sensitizing community members focusing on parent-child communication about sex related issues.

- Youth and women affairs should take the initiative in the promotion of school adolescents' sexual health in collaboration with each school administration and different stakeholders including health sector.

- Strengthen Youth-serving agencies, churches, Sunday Schools, community and social organizations to develop strategies that promote high levels of parent-youth-connectedness.

- Further research should be conducted comparative study on risky sexual behavior among in-school and outschool youths, and its contributing factors and consequences. 


\section{References}

Abdullahi. M. \& Umar. A. (2013).Consequences of Pre-Marital Sex among the Youth a Study of University of Maiduguri. Nigeria, Volume 10, International Journal of Humanities and Social Science Invention, volume 2(10), pp 10-17. www.Iosrjournals.Org.

Abu P.B \& Akerele E.O. (2006). Parental Influence on Adolescents Sexual Behavior in Ibadan North Local Government Area of Oyo State, Nigeria. International Journal of African \& African American Studies Vol. 5, No. 1.

Adeoye, Ayodele .O, Ola, Omolayo and Aliu, Bose. (2012). Prevalence of premarital sex and factors influencing it among students in a private tertiary institution in Nigeria. International Journal of Psychology and Counseling Vol. 4(1), pp. 6-9.

Alano. A, Yifru B and Dejene H. (2014). Pattern of Sexual Behavior of Hawassa University Students, Ethiopia: Hawassa University, College of Medicine and Health Sciences. International STD Research \& Reviews 2(2): SCIENCEDOMAIN international www.sciencedomain.org.

Alemayehu.M. (2006). Assessment of the prevalence of premarital sex and unprotected sexual practice among Gedeo zone high school students, SNNPR, Ethiopia.

Alemu A, Letta S and Demessie M. (2015). Premarital sexual practice and its associated factors among high school adolescents in kolfe keraniyo sub city, Addis Ababa, Ethiopia. International Journal of Development Research Vol. 5(02), pp. 3359-3364.

Ayalew M, Mengistie B and Semahegn A. (2014). Adolescent - parent communication on sexual and reproductive health issues among high school students in Dire Dawa, Ethiopia. Reproductive Health 11:77. http://www.reproductive-health-journal.com.

Basel PL. (2013). Premarital Sex Behaviors among College Youths of Kathmandu, Nepal. Kathmandu University. Kathmandu University Medical Journal. Vol, 41(1): pp 27-31.

Blum, R.W., Mmari, Kristin Nelson. (2005). Risk and Protective Factors Affecting Adolescent Reproductive Health in Developing Countries Department of Population and Family Health Sciences Johns Hopkins Bloomberg School of Public Health 615 N. Wolfe Street,E4527, Baltimore, MD 2120.

Bogale, A and Seme, A (2014). Premarital sexual practices and its predictors among in-school youths of Shendi town, west Gojjam zone, North Western Ethiopia. http://www.reproductive-healthjournal.com/content/11/1/49.

Bukar M, Audu BM, Kawuwa MB, Ibrahim SM and Ali F. (2013). Determinants of premarital sex in Maiduguri, Nigeria: Implications for Human Papilloma Virus vaccination. University of Maiduguri Teaching Hospital, Borno state, Nigeria. International Journal of Medicine and Biomedical Research Volume 2 Issue 3.

Dadi AF and Tekilu FG. (2014). Risky Sexual Behavior and Associated Factors among Grade 912 Students in Humera Secondary School, Western Zone of Tigray, Ethiopia. Science Journal of Public Health. Vol. 2, No. 5, pp. 410-416.

DeJong J, Shepard B, Roudi F.F, and Ashford L, (2007). Young people's sexual and reproductive health in the Middle East and North Africa. Population Reference Bureau.

Dekeke GD \& Prof. Sandy PT. (2014). Factors influencing sexual risk behaviors among senior secondary school students (youths). Master of Public Health in the subject Health Studies at the University of South Africa. International Journal of Scientific and Research Publications, Volume 4, Issue 8.

Derese A, Seme A and Misganaw. C. (2014). Assessment of Substance Use and Risky Sexual Behavior among Haramaya University Students, Ethiopia. Science Journal of Public Health. Vol. 2, No. 2, pp. 102-110.

Duncan, Boisjoly J, Kremer M, Dan M. Levy and Eccles J. (2005). Peer Effects in Drug Use and Sex among College Students. Journal of Abnormal Child Psychology, Vol. 33, No. 3, pp. 375-385.

Endazenaw G and Abebe M. (2015). Assessment of Premarital Sexual Practices and Determinant Factors among High School Students in West Shoa Zone, Oromia Regional State, Ethiopia. Science Journal of Public Health. Vol. 3, No. 2, pp. 229-236.

Fekecha H, Tebeje B, Megersa H (2014). Prevalence of pre-marital sexual practices and associated factors among Jimma Teacher Training College students in Jimma Town, Oromia Region, Ethiopia. J Women's Health Care. V 4(1): P.221.

Ferguson, R.D. (2013). Health and Health-Related Behaviors University of Minnesota-Twin Cities Students. College Student Health Survey Report Boynton. V 4: Pp 323-329.

FHAPCO. (2014). Country progress report on the HIV response, Federal Democratic Republic of Ethiopia.

Flood, M. (2009). Youth, Sex, and the Internet. Counseling, Psychotherapy, and Health, the Use of Technology in Mental Health Special Issue, volume 5(1), pp 131-147.

Gama, J. (2009). An assessment of the capacity of faculty-based youth friendly reproductive health services to promote sexual and reproductive health among unmarried adolescents: evidence from rural Malawi. PhD thesis. Queen Margaret University. http://etheses.qmu.ac.uk/132/.

Gebremedhin G, kidanemariam A, Tadesse Z, Berhane Y, G/medhin H, Desalegn B,G/her G and kalayu A 
(2015). Assessment of sexual behaviors and associated factors among Sheba University College students in Mekele Town, Tigray, Ethiopia. International Journal of Pharmaceutical and Biological Sciences Fundamentals, Vol. 10(01). WWW.IJPBSF.COM.

Gemechu.E. (2014). Premarital Sexual Practice among Unmarried First Year Undergraduate Students in Alkan University College in Addis Ababa, Ethiopia. Global Journal of Medicine and Public Health. Vol. 3, No. 2.

Ghaffari M, Gharlipour ZG, Mehrabi Y, Ramezankhani A and Movahed A. (2014). Premarital Sexual Intercourse-Related Individual Factors among Iranian Adolescents: A Qualitative Study. Iran. Iran Red Crescent Med J. volume; 18(2).

Girma D, Hailu G, Ayana M and Ketema K. (2015). Factors Early Sexual Initiation among Governmental Preparatory School Students, Addis Ababa, Ethiopia. Journal of Community Medicine \& Health Education. Volume 5.Issue 1:pp.333.

Jackson K. (2011). Causes and characteristics of pre-marital sex among the youths of Madudu sub county, Mubende district. Makerere University. P. 41.

Khalaj F, Farahani A, Cleland J and Mehryar A.H. (2011). Associations between family factors and premarital heterosexual relationships among female college students in Tehran.

Kline. A. (2014). The Effects of HIV/AIDS Knowledge during Adolescence: The Role of This Knowledge in Predicting Sexual Behaviors and Outcomes. University of Michigan.

Kroone.M. (2010). School related gender based violence at the secondary school in the region Boukombe in the north of Benin and the general situation in West Africa.

Kumari P and Bhushan CT. (2014). Comparative Study of Premarital Sexual Behavior among Hindu and Muslim Females in Gopalganj District of Bihar. Scholars Journal of Arts, Humanities and Social Sciences; volume 2(3B): pp 445-447.

Laddunuri, MM PhD (2013). Sexual Behavior of Secondary School Adolescent Students in Tanzania: Patterns and Trends. International Journal of Caring Sciences. V 6/ 3, p.472.

Layte.R, McGee.H, Quail.A, Rundle.K, Cousins.G, Donnelly.C, Mulcahy.F, Conroy.R. (2006). Irish Study of Sexual Health and Relationships (ISSHR). Crisis Pregnancy Agency and the Department of Health and Children.

Legesse E. (2014). Determinants of Risky Sexual Behavior, Relation between HIV Risk Perception and Condom Utilization among Wollega University Students in Nekemete Town, Western Ethiopia. Science, Technology and Arts Research Journal.v3(3): p 75-86.

Mashau, T.D. (2011). Cohabitation and premarital sex amongst Christian youth in South Africa today: A missional reflection', HTS Teologiese Studies/Theological Studies. Vol 67(2).

Mbelle N, Setswe G, Sifunda S, Mabaso M, Maduna V . (2014). HIV and AIDS related Knowledge, attitudes and behaviors of students and staff at South Africa's technical and vocational education and training colleges.

Mehra D. (2013). Sexual Behavior among Ugandan university students: A gender perspective. Lund University, Sweden.

Millennium Development Goals Report. United Nations New York, 2015.

Millennium Development Goals Report. United Nations New York, 2014.P 35

Mohammadyari G. (2014). The Relationship between Parental Style and Attitude to Premarital Sex among Students: A Case Study in Iran. International Journal of Psychology and Behavioral Research. Vol., 3(1), pp 24-28.

Morris.J and Rushwan.H. (2015). Adolescent sexual and reproductive health: The global challenges. International Federation of Gynecology and Obstetrics, London, UK. Journal homepage: www.elsevier .com/locate/ijgo.

Musa, Audu B, Kawuwa M, Ibrahim SM, Ali F. (2013). Determinants of premarital sex in Maiduguri, Nigeria: Implications for Human Papilloma Virus vaccination. Volume 2 Issue 3 September - December 2013.

Nambambi N. M and Mufune .P (2011). What is talked about when parents discuss sex with children: Family based sex education in Windhoek, Namibia .Department of Sociology, University of Namibia. African Journal of Reproductive Health; v 15(4): p 120.

National Student Sexual Health HIV Knowledge, Attitude and Behaviors Survey. (2014). Focusing on Student Men who have Sex with Men at 14 Higher Education Institutions in South Africa.

Netsanet F, Abebe M, and Tsion A. (2013). Living with parents and risky sexual behaviors among preparatory school students in Jimma zone, South west Ethiopia. African Health Sciences; volume 13(2): pp 498 - 506 http://dx.doi.org/10.4314/ahs.v 13(2.42).

Odu.BK and Akanle.FF. (2008). Knowledge of HIV/AIDS and Sexual Behavior among the Youths in South West Nigeria. University of Ado-ekiti, Ekiti State. Humanity \& Social Sciences Journal 3 (1): 81-88.

Okeh (2009). Dressing Code and Sexual Characteristics of Younger Population in South Eastern Nigeria. Department of Industrial Mathematics and Applied Statistics, Ebonyi State U University Abakaliki, Nigeria. 
Research Journal of Mathematics and Statistic, volume 1(1): pp 14-18.

Oluwatoyin RN, F.E and Modupe O. RN, O (2014). Risky Sexual Behavior among Secondary School Adolescents in Ibadan North Local Government Area, Nigeria. IV (May-Jun. 2014), PP 34-44

Ounjit.W(2011). Pre-marital Sex and Pregnancy: the High Price of Forgiveness. Mahasarakham University, Thailand. International Journal of Social Science and Humanity, Vol. 1, No. 2.

Prasad, Dr. P S Vinoth Kumar and Ms. R Poovitha. (2014). Premarital Sex and Age at First Sex among Collegiate Men in Pondicherry, India - Cross Sectional Study. Scholars Academic Journal of Biosciences (SAJB), India; volume 2(9): pp 618-622.

Regmi P. R, Simkhada P and van Teijlingen E.R (2010). There are too many naked pictures found in papers and on the net": Factors encouraging premarital sex among young people of Nepal. Health Science Journal. Volume 4, Issue 3.

Regnerus MD (2005). Religion and Patterns of Parent-Child Communication about Sex and contraception. Department of Sociology, University of Texas at Austin. The Sociological Quarterly 46: pp 79-105.

Reza M, Moghaddam H, Eftekharzadeh-IM, Fathimoghadam F and Javad SP (2015). Sexual and Reproductive Behaviors among Undergraduate University Students in Mashhad, a City in Northeast of Iran. J Reprod Infertil, Vol 16, No 1, pp: 43-48.

Seme.A and Wirtu.D. (2006). Premarital Sexual Practice among School Adolescents in Nekemete Town, East Wollega. Ethiopia. Ethiop.J.Health Dev. 2008; 22(2).

Teklemariam.W. (2013). Female College Students' Knowledge, Attitude and Practice Towards sex and emergency contraceptives. University of South Africa.

Tura.G, Alemseged F, Dejen.S (2012). Risky sexual behavior and predisposing factors among students of Jimma University, Ethiopia. Ethiop J Health Sci. Vol. 22, No. 3.

Vasudevan.H, (2013). Sexual problems among teens in Malaysia: a case study at youth rehabilitation centre in Kuala Lumpur, Malaysia. Interdisciplinary Journal of Contemporary research in Business; Vol 5, No 4.

Wang'eri.T \& Habil Ferd Otanga (2013). Family, peer and protective factors related to sex behavior among urban adolescents in secondary schools in Mombasa County, coast province, Kenya. International Journal of Education and Research; Vol. 1 No. 5.

Wepukhulu, R.N., Mauyo, L.W., Poipoi, M.W., Achoka, J.S.K., Kafu, P. and Walaba, A. A. (2012). Influence of Socio-Economic Status on Attitude towards Premarital Sex among Secondary School Students in Western Kenya: Case Study of Bungoma County, Kenya. Journal of Emerging Trends in Economics and Management Sciences .v 3(4): p 298-301.

WHO. (2006). Alcohol Use \& Sexual Risk Behavior: A Cross-Cultural Study in 8 Countries. Geneva. Mental Health: Evidence \& Research Management of Substance Abuse.

Yousri.Y and Mamdouh.H.M. (2013). Mother-daughter communication about sexual and reproductive health in Alexandria, Egypt. www.popcouncil.org.

Zimuto J \& Chikodza .E. (2013). A consumer evaluation of modernity on women's dressing. Great Zimbabwe University, Zimbabwe. International Refereed Research Journal. Www.researchersworld.com. Vol 4, Issue 2 .

\section{Annex 5: Biography sketch}

My Manale Andargie Embiyale, I was born on 7th September 1987 in Amhara Regional State, Ethiopia. I attended my elementary, secondary and preparatory education at Boda Baradi, Woin Woha and Motta Schools respectively. Then, in 2008 I joined to Hawassa University College of agriculture and graduated with BSc in Rural Development and Family Sciences in 2010. My professional career started in Alage Technical Vocational Education and Training College, Ministry of Agriculture and Natural Resource as an instructor from 2012 -2018. While on job, I rejoined to Hawassa University to pursue my postgraduate study in July 2014 in the related field of Gender and Family Study. Now I am a lecturer in Debremarkos University, College of Agriculture, Ethiopia. 